\title{
Serine/Threonine Kinase Inhibitor XL418
}

National Cancer Institute

\section{Source}

National Cancer Institute. Serine/Threonine Kinase Inhibitor XL418. NCI Thesaurus. Code C68963.

A selective, orally active small molecule, targeting protein kinase B (PKB or AKT) and ribosomal protein S6 Kinase (p70S6K), with potential antineoplastic activity. XL418 inhibits the activities of PKB and p70S6K, both acting downstream of phosphoinosotide-3 kinase (PI3K). These kinases are often upregulated in a variety of cancers. Inhibition of PKB by this agent will induce apoptosis, while inhibition of p7056K will result in the inhibition of translation within tumor cells. 